\title{
Mitochondria in the human heart
}

\author{
H. Lemieux • C. L. Hoppel
}

Published online: 8 April 2009

(C) The Author(s) 2009. This article is published with open access at Springerlink.com

\begin{abstract}
The heart relies mainly on mitochondrial metabolism to provide the energy needed for pumping blood to oxygenate the organs of the body. The study of mitochondrial function in the human heart faces many obstacles and elucidation of the role of mitochondria in cardiac diseases has relied mainly on studies with animal models. Cardiac diseases are the leading cause of mortality worldwide. With the emergence of new therapies to treat and prevent heart disease, some aiming at metabolic modulation, a need for acquiring a better understanding of mitochondrial function in the human heart becomes apparent. Our review is aimed at specific evaluation of the human heart in terms of (1) methods to understand mitochondrial function, with particular emphasis on integrated function, (2) data on the role of mitochondrial dysfunction in cardiovascular disease, and (3) possible applications of this knowledge in the treatment of patients with cardiac disease.
\end{abstract}

Keywords Oxidative phosphorylation - Electron transport complexes $\cdot$ Heart failure $\cdot$ Mitochondrial defect .

Permeabilized fibers

\section{Introduction}

The rhythmic contraction of the heart ensures oxygenation of the organs of the body. Most of the energy needed for this

H. Lemieux $(\bowtie) \cdot$ C. L. Hoppel

Center for Mitochondrial Disease,

Department of Pharmacology and Medicine,

School of Medicine, Case Western Reserve University,

10900 Euclid Avenue,

Cleveland, OH 44106, USA

e-mail: helene.lemieux@case.edu arduous task is provided by mitochondrial metabolism, which produces a high-energy molecule, adenosine triphosphate (ATP). The process of energy production by mitochondria is called oxidative phosphorylation (OXPHOS), because it involves the coupling of oxygen to phosphorylation of ADP into ATP. The human heart daily synthesizes approximatively $30 \mathrm{~kg}$ of ATP (Ferrari et al. 2006).

In the failing heart, a decrease in energy reserves has been measured by phosphorus-31 NMR spectroscopy. This technique facilitates in vivo exploration of intracellular metabolism. A low phosphocreatine-to-ATP ratio ( $\mathrm{PCr} /$ ATP), indicating a cardiac energy deficit, has been shown in the failing human heart (Beer et al. 2002; Conway et al. 1991; Hardy et al. 1991; Neubauer et al. 1997; Neubauer et al. 1992). This ratio is correlated with clinical symptoms (Conway et al. 1998) and predicts mortality better than the left ventricular ejection fraction (Neubauer et al. 1997). As the main energy source, mitochondria are suspected to be at least in part responsible for the low energy reserve in the failing heart (Mettauer et al. 2006). The NMR approach, however, does not reveal intrinsic mitochondrial content or function, even if it often has been interpreted as such.

Little information is available on mitochondrial function in the human heart. Most of the studies on the role of mitochondria in cardiac diseases have relied on animal models, which may not be representative of the human. However, tissue samples of the human heart are routinely removed in standard surgery (atrium cannulation, heart transplantation, cardiac biopsies), providing a resource that is underutilized for research on mitochondrial physiology and pathophysiology. The development of new methods to study mitochondrial function provides an opportunity to use the small amount of tissue available from routine surgeries to understand mitochondrial function. Our review 
is aimed at evaluating (1) the different methods available to understand mitochondrial function in the human, (2) the state of knowledge of the role of mitochondrial dysfunction in heart diseases, and (3) the possibility of applying this knowledge in the treatment of patients with cardiac diseases.

\section{Methods to study human heart mitochondria}

OXPHOS involves several interacting pathways. As a first step, most substrates for mitochondrial metabolism enter by transporters and are metabolized to produce reducing equivalents, usually through the action of dehydrogenases. For example, pyruvate is transported by the monocarboxylate transporter and dehydrogenated by the pyruvate dehydrogenase complex in the matrix, generating NADH and acetyl CoA. Fatty acids are transported by a complex carnitine transporter system and then go through betaoxidation to generate $\mathrm{NADH}, \mathrm{FADH}_{2}$, and acetyl CoA (Kerner and Hoppel 2000). The TCA cycle, which produces NADH and $\mathrm{FADH}_{2}$, funnels electrons into the electron transport complexes (ETC). The electron transport system is composed of four ETC: Complexes I (CI, NADHubiquinone oxidoreductase), II (CII, succinate ubiquinone oxidoreductase), III (CIII, ubiquionol-cytochrome $c$ oxidoreductase), and IV (CIV, cytochrome $c$ oxidase), and two main electron carriers (ubiquinone and cytochrome $c$ ). The transfer of electrons through three complexes coupled to the pumping of protons into the space between the inner and outer mitochondrial membranes creates a proton gradient, which drives the ATP synthetase in the inner membrane to produce ATP. The other substrates for the ATP synthetase are transported through the mitochondrial inner membrane by the adenine nucleotide translocase (ANT) and the phosphate carrier. The resulting matrix ATP is transported into the intermembrane space by ANT where mitochondrial creatine kinase $(\mathrm{CK})$ catalyzes the transfer of the highenergy phosphate to creatine, which is stored in the form of cytosolic PCr for later use by the cardiac fibers for contraction.

Impaired mitochondrial function may be related to any steps involved in this complex process, either in term of the quantity, the concentration, or the functionality of the different components, or their interaction. Even in the face of the pivotal importance of mitochondrial energy production in the human heart, mitochondrial function unfortunately has not been studied in any depth. This part of the mini-review is aimed at providing a summary of the different methods available to enhance our knowledge of mitochondrial pathophysiology. Particular emphasis will be placed on methods allowing the measurement of integrated mitochondrial functions.

\section{Activities of mitochondrial enzymes}

In attempts to identify possible causes for a decline in mitochondrial function in diseased hearts, most studies have focused on the measurement of enzyme activities (EA, Table 1). The spectrophotometric assays for enzyme activities can be performed on isolated mitochondria, but the majority of the studies used homogenates of tissue, especially when the amount of tissue available was too small for isolation of mitochondria. Tissues or mitochondria can be used fresh or frozen for analysis, but some enzymes lose activity if frozen (Rustin et al. 1994). The measurement of mitochondrial enzyme activities yields valuable information about the capacity of some steps involved in mitochondrial metabolism, but has an important limitation when the objective is to evaluate the capacity of energy production by the whole system. The measurements are performed in mitochondria with permeabilized inner membrane, removing the transport barriers. Furthermore, the complex regulation of OXPHOS in vivo is not taken into account. For example, CIII and CIV are known to be present in amounts larger than needed to support the maximal electron flow in the ETC in human skeletal muscle (Kunz et al. 2000) and in human cells (Villani and Attardi 1997; Villani et al. 1998). The functional impairment in the pathway appears only when the capacity of the enzyme is reduced below the threshold activity (Rossignol et al. 2003). The excess capacity is highly variable in different tissues and species (Rossignol et al. 2000) and is unknown in the human heart. Thus, an apparent reduction in the activity of single step may have no effect on the whole process.

\section{Integrated mitochondrial function-OXPHOS}

To understand the effect of mitochondrial dysfunction in the pathophysiology of the human heart, a more integrative approach is to look at the process of OXPHOS by polarographic measurement of oxygen consumption in mitochondria in the presence of specific substrates that feed electrons into different sites of the ETC (Puchowicz et al. 2004). For example, in the presence of pyruvate + malate or succinate (+rotenone), the electrons fed into CI or CII, are transferred to ubiquinone, CIII, and CIV, where oxygen plus hydrogen are converted into water. Substrates derived from carbohydrate, amino acids, or fatty acids oxidation can be used to evaluate mitochondrial function. Oxygen consumption in the presence of ADP is coupled to the production of ATP by the phosphorylation system. The measurement of oxygen consumption in the absence of ADP (or after its complete consumption) is used as an estimation of the proton leak, i.e., the protons not used to phosphorylate the ADP. Uncouplers also can be added to 
dissociate the proton gradient in the intermembrane space and to look at the limitation of the electron transport by the phosphorylation system. The measurement of OXPHOS assesses multiple components of mitochondrial metabolism and can uncover defects and differences in mitochondrial function not apparent by other techniques.

\section{Isolated mitochondria}

The conventional measurement of OXPHOS is performed after isolation of mitochondria from fresh tissue. The entire population of heart mitochondria can be isolated as a whole or, if the amount of tissue is sufficient, the subsarcolemmal and interfibrillar mitochondrial populations can be harvested separately (Palmer et al. 1977). The two populations have been shown to be differentially affected in an animal model of cardiomyopathy (Hoppel et al. 1982). The subpopulations of mitochondria were separated in cardiac tissue from patients undergoing a mitral valve replacement (Weinstein et al. 1986), but no information is available at present on the involvment of those populations per se on human cardiac pathophysiology.

The differential isolation of mitochondrial subpopulations requires a substantial amount of tissue available from the explanted heart of patients undergoing transplantation, but the roadblock is the difficulty in obtaining tissue from control healthy human heart. In enzymatic or genetic studies, autopsy samples often are used as controls (Table 1, groups CA), but they are, in some cases, taken several hours after death and cannot be used for OXPHOS measurements. A control group for OXPHOS measured in isolated mitochondria depends mostly on the availability of scarce donor hearts for transplantation that for some reason end up not being used.

\section{Permeabilized fibers}

The permeabilized fiber method (Veksler et al. 1987) allows the analysis of mitochondrial function in only a few milligrams of muscle tissues. Based on the selective permeabilization of the sarcolemma by mechanical separation with forceps and by exposure to a low concentration of saponin, the mitochondria can be studied in their cellular environment, depleted of cytosol, but with a functionally and morphologically intact architecture (Kunz et al. 1993; Kuznetsov et al. 2008; Saks et al. 1998). As for isolated mitochondria, different substrates, inhibitors, and uncouplers can be used to assess the OXPHOS pathway. With permeabilized myocardial bundles, both subsarcolemmal and interfibrillar mitochondrial populations are evaluated (Veksler et al. 1987).

This technique offers several advantages for the study of the human heart because it is possible to make measurements on very small amounts of tissue taken 1) during cardiac biopsy, e.g., for the follow up of rejection criteria in patients after a heart transplantation, 2) during routine surgery, e.g., removal of the atrial appendage (or part of it) before cannulation of the atrium and 3) from the donor heart when implanted into the recipient, overcoming the major problem of lack of control group in many studies. This technique is particularly attractive in combination with high-resolution respirometry (Oroboros, Innsbruck, Austria), making it possible to detect small differences in respiratory function. A possible limitation of this method is that sensitivity of respiration in response to the addition of substrates or inhibitors can be altered by inadvertent inclusion of non-mitochondrial structures such as myofibrillae and cells of non-myocyte origin, but the bias exists for normal and sick patients alike. Furthermore, the heterogeneity of structures in the tissues may lead to more variability between replicate measurements on different pieces of myocardial tissue from the same patient.

\section{Anatomical sites in the heart}

Another important problem in the study of the human heart is the different myocardial anatomical sites that are used as sources during diverse surgeries, with different chambers available from the explanted heart during transplantation (left and right atrium and ventricles), from surgeries requiring cardiopulmonary bypass (right atrial appendage), from biopsies (interventricular septum), and from the donor heart (left atrium). In end-stage heart failure (HF) patients undergoing transplantation, the rate of respiration in fibers per mg protein (Sharov et al. 2000) or in isolated mitochondria per mg mitochondrial protein (Lee et al. 1998) was similar in both ventricles. In fibers from atrial appendages, the respiration rate with all substrates is lower compared to ventricles, showing the decrease in mitochondrial content, but when OXPHOS was corrected for the amount of mitochondria (using the maximum uncoupled respiration) the respiration was similar in the three chambers (Lemieux et al. 2008).

The importance of studies focused on the mitochondrial function in the human heart

Animal models are of great utility for the study of cardiomyopathies and HF, but such studies may not explain the mitochondrial defect occurring in the failing human heart. The first reason is the major differences in history of the disease and degree of decompensation between animals and humans (Scheubel et al. 2002). A second could be the special features of human heart mitochondria (vida infra). Compared to human skeletal muscle, the activity of citrate synthase (CS) is three-fold higher in the human heart (18.6 and $58.6 \mathrm{umol} / \mathrm{min} / \mathrm{g}$ tissue for skeletal muscle and heart, 


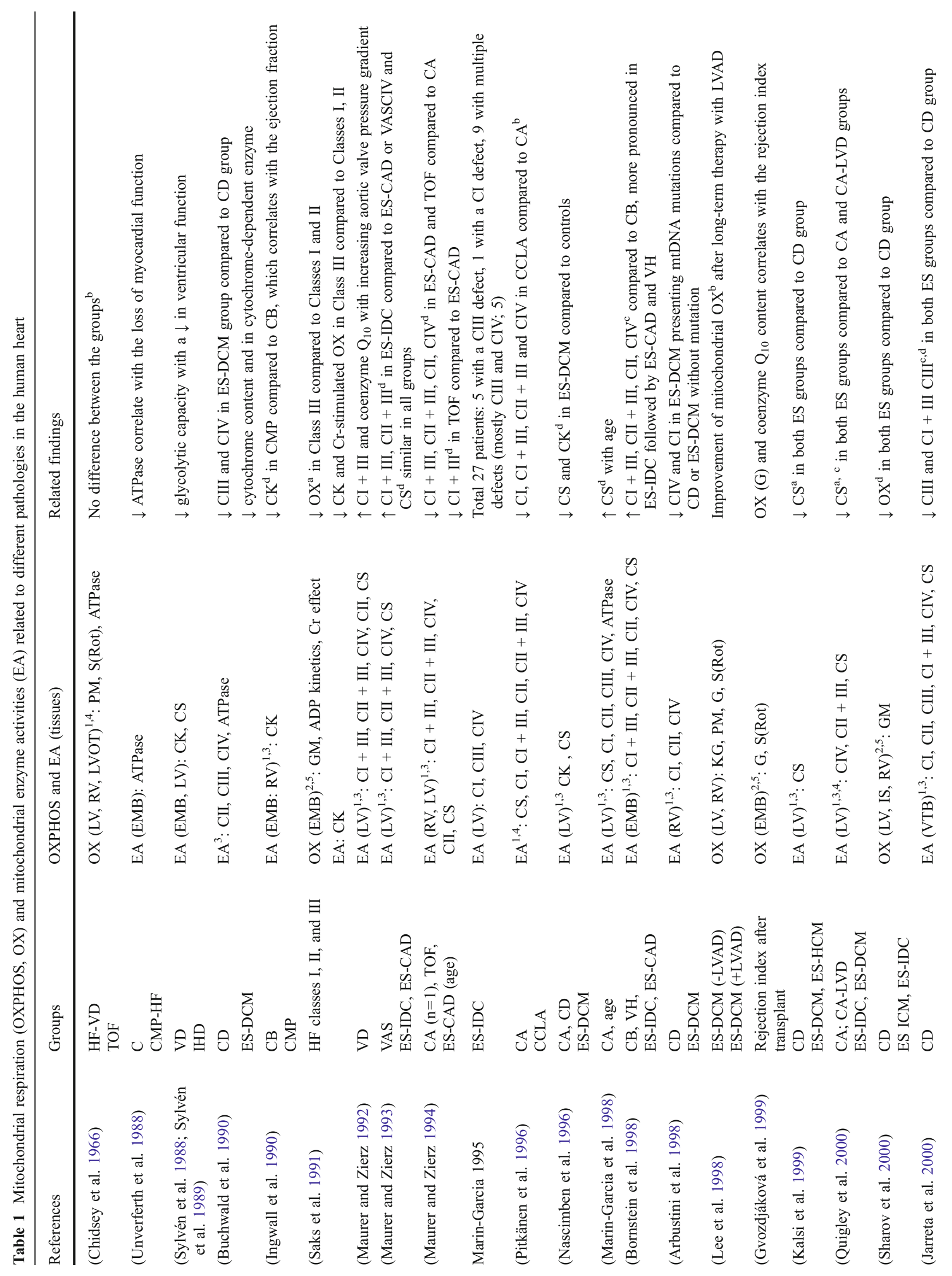



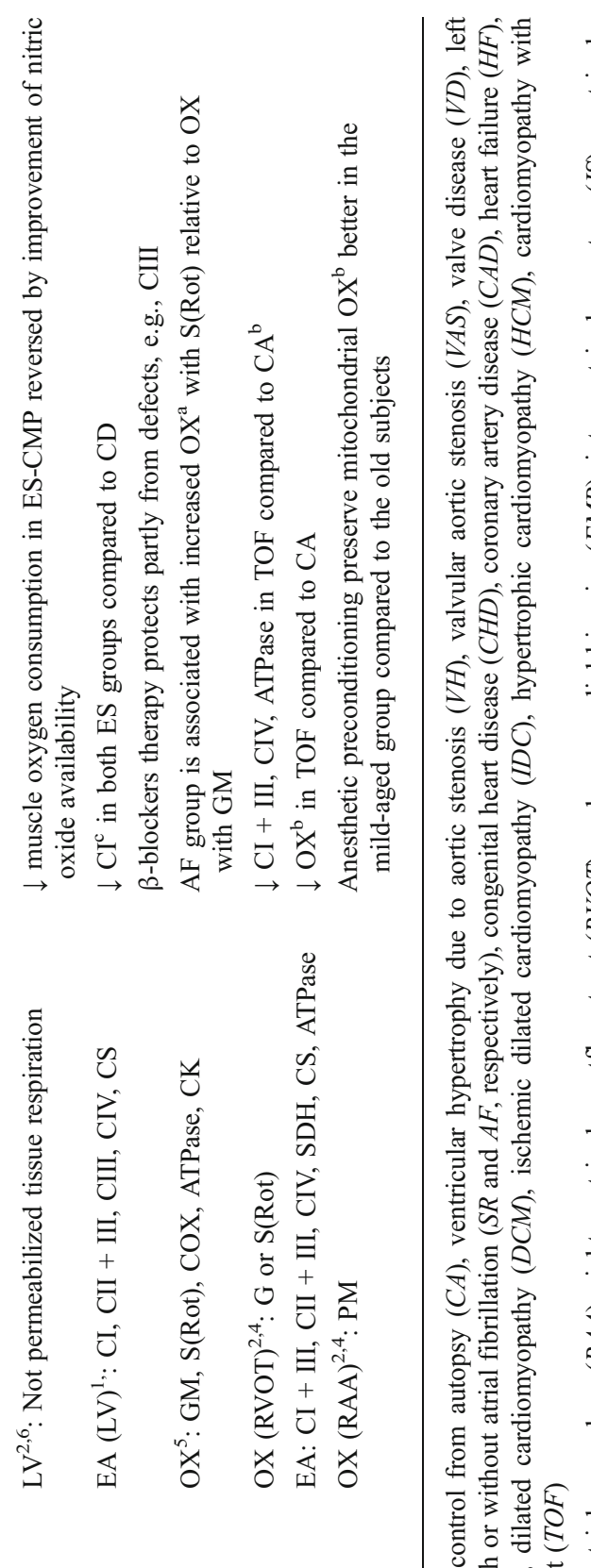

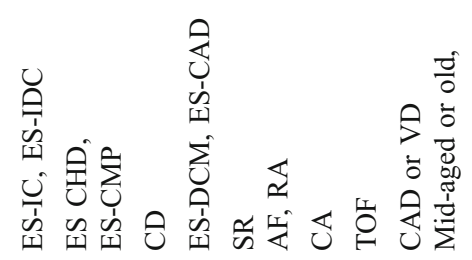

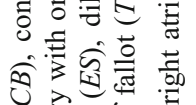

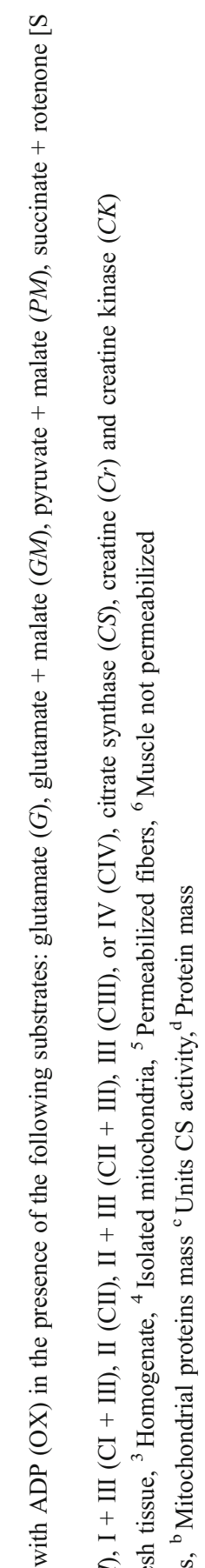

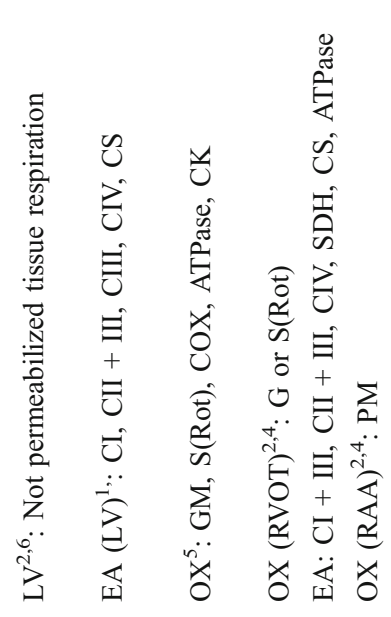

记

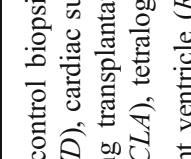

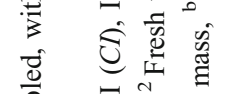

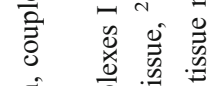

¿.

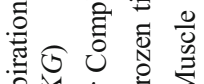

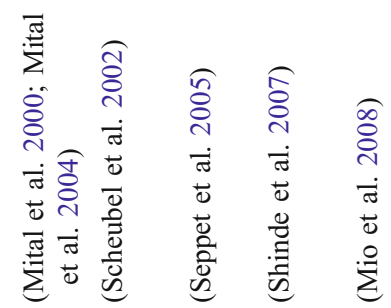

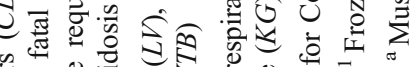

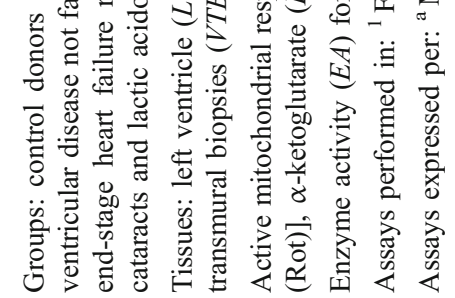


respectively, unpublished data), in accordance with a threefold increase in activity of CI, CII, CIII (unpublished data). The respiration rate of the human left ventricle is similar to human skeletal muscle (reviewed by (N'Guessan et al. 2004), and lower in the cardiac atrial appendage (Gellerich et al. 1994). With more mitochondria and more ETC activity in the human heart compared to skeletal muscle, why is the OXPHOS capacity not higher? Part of the explanation comes from the impressive limitation of OXPHOS capacity by the phosphorylation system in human heart mitochondria. The respiration coupled to the production of ATP was about $40 \%$ of the maximal capacity of the electron transport (measured after uncoupling) in the human heart (Lemieux et al. 2008) compared to $80 \%$ in the human skeletal muscle (Boushel et al. 2007). In mice and rats, however, OXPHOS capacity is much higher in heart compared to skeletal muscle, and the phosphorylation system in both tissues exerts almost no limitation on maximal OXPHOS capacity (Aragonés et al. 2008; Lemieux et al. 2006). Calcium accumulation by human heart mitochondria also was shown to be lower than in the hearts of a variety of animals (Lindenmayer et al. 1971). These examples showed the particularities of the human heart mitochondria that can be seen only by studying OXPHOS. It reinforces the importance of achieving a better understanding of the regulation of mitochondrial metabolism specifically in the human heart.

\section{Mitochondrial dysfunctions in human heart: current knowledge}

Table 1 presents an overview of knowledge of mitochondrial dysfunctions, enzyme activities, and OXPHOS in diseases of the human heart. Most of these studies concern HF, a complex, multifactorial syndrome resulting in the chronic and progressive loss of ventricular function leading to both cardiac and systemic perturbations. A number of underlying causes can lead to HF, including ischemic heart disease (coronary heart disease, myocardial infarction, and hypertension), cardiomyopathy (dilated, hypertrophic), valvular disease, and alcohol/drug-induced heart disease. In general, HF is preceded by an initial insult, e.g., cardiomyocyte loss or persistently increased workload, which activates compensatory mechanisms such as hypertrophy. In the short term, the compensation apparently restores cardiovascular function but the sustained activation of compensatory mechanisms can lead to secondary heart damage, i.e., deleterious alterations in ventricular mass, chamber size, and shape, leading to incapacity of the heart to meet the needs of the body (Latronico et al. 2008).

Most of the previous studies on mitochondrial function in human HF compared donor hearts with hearts from patients at end-stage $\mathrm{HF}$ at the time of transplantation (Table 1, ES groups, most of them in class III or IV of the New York Heart Association). End-stage HF was associated with multiple mitochondrial functional injuries, e.g., a decrease of ETC activities per muscle mass, most notably CI (Scheubel et al. 2002), CIII (Buchwald et al. 1990; Jarreta et al. 2000; Marin-Garcia et al. 1995), and CIV (Arbustini et al. 1998; Quigley et al. 2000), and a decrease in OXPHOS capacity in the presence of substrates directing electrons into CI in permeabilized fibers (Saks et al. 1991; Sharov et al. 2000). Part of the loss of mitochondrial ETC activity or OXPHOS per $g$ of muscle is explainable by a decrease in mitochondrial content occurring also in endstage HF (Kalsi et al. 1999; Nascimben et al. 1996; Quigley et al. 2000). The similarity in CS activity between end-stage HF and control groups (Maurer and Zierz 1994) may be explained by the age differences between groups, because the CS activity increases with age (Marin-Garcia et al. 1998). The decrease in mitochondrial content is not the only defect occurring in severe $\mathrm{HF}$ as the activity of $\mathrm{CI}$ (Scheubel et al. 2002) and CIII (Jarreta et al. 2000) expressed over the CS activity also significantly decreased.

It previously has been suggested that mitochondrial uncoupling occurs in HF patients. This uncoupling may offer a cardioprotective effect, reducing ROS production (Chen et al. 2007), but also would result in a further loss of cardiac efficiency by allowing protons to re-enter the matrix without ATP synthesis (Murray et al. 2007). The proposed uncoupling in heart disease is supported by increased cardiac levels of uncoupling protein 3 in patients undergoing coronary artery bypass surgery (Murray et al. 2004). While the decrease in respiratory control in end-stage HF has been used in support of uncoupling (Murray et al. 2007), the decrease in respiratory control is explained by the decrease in State 3 respiration rather than by an increase in leakage (Sharov et al. 2000); this is not uncoupling. Other evidence also shows that coupling is preserved in $\mathrm{HF}$ mitochondria (Chidsey et al. 1966) even at a late stage of the disease (Lemieux et al. 2008).

A disturbance of the phophorylation system also occurs in severe HF. In dilated cardiomyopathy, an upregulation (Sylven et al. 1993) and an increase in concentration (Schultheiss 1992) of the ANT carrier has been shown. This carrier upregulation, however, was associated with a decrease in function (Dörner et al. 2006; Dörner et al. 1997; Schultheiss 1992), explained by a change in the expression pattern of the ANT isoforms, i.e., increase in ANT1 and decrease in ANT2 (Dörner et al. 2006; Dörner and Schultheiss 2000; Dörner et al. 1997). ATPase activity also has been shown to be decreased in the failing human heart, but at least part of the decrease is explained by the decrease in mitochondrial content (Unverferth et al. 1988). The energy buffering and transfer capacity into the cells is 
compromised in end-stage HF, partly due to a decrease in CK activity (Khuchua et al. 1992; Saks et al. 1991) and a diminution of creatine concentration (Kalsi et al. 1999; Nascimben et al. 1996). These observations agree with P NMR studies suggesting that a low PCr/ATP ratio is a consequence of the creatine pool depletion.

Interestingly, despite different clinical manifestations, end-stage HF from different etiology (dilated, hypertrophic, or ischemic cardiomyopathies) seems to end up with the same key changes in mitochondrial metabolism (Jarreta et al. 2000; Kalsi et al. 1999; Scheubel et al. 2002; Sharov et al. 2000), with the exception of the modification in the ANT isoforms, which is specific to dilated cardiomyopathy (Dörner and Schultheiss 2000).

The data on mitochondrial dysfunction acquired in patients during the end-stage HF do not help in understanding the involvement of mitochondria in the development of the disease. To determine whether alterations of mitochondrial function plays a primary or a secondary role in HF, we need to study patients at an early stage of HF or with pathologies that lead to HF, but when compensatory mechanisms still can maintain the cardiac output. Unfortunately, such data are rare, mostly limited to very specific enzymatic analysis and/or lack of an appropriate control group (see Table 1). The varying methods used in different laboratories make it difficult to compare the data between studies. Whether the impairment of mitochondrial function is primary or secondary in the development of HF remains to be elucidated, as is the localization of the defect in mitochondria.

\section{Mitochondrial function in the prevention and treatment cardiac diseases}

A few studies have shown that some treatments for severe HF improved mitochondrial function and structure, e.g., longterm implantation of left ventricular assist devices improved OXPHOS capacity (Lee et al. 1998), beta-blocker therapy reversed part of the defect in ETC activity (Scheubel et al. 2002), and administering a beta-adrenoceptor agonist increases cristae-to-matrix ratio and mitochondrial size (Unverferth et al. 1980). An evolving trend in the treatment of cardiac disease is the use of metabolic modulators, including therapeutic targets aimed at improving mitochondrial energy production (reviewed by Murray et al. 2007) to prevent or reverse the low energy status of the failing heart. The application of those therapies requires a better understanding of cardiac mitochondrial function. Severe HF is associated with a reversion of cardiac metabolism from a use principally of free fatty acid metabolism in the healthy heart to enhanced glucose oxidation in the failing heart (Tuunanen et al. 2008). Glucose oxidation is favored during hypoxia or ischemia, as a more oxygen-efficient substrate (Abozguia et al. 2006). The administration of metabolic regulators increasing carbohydrate oxidation, e.g., propionyl L-carnitine, has been shown to improve ATP production in the human heart (Bartels et al. 1992). There is, however, no information on fatty acid oxidation by mitochondria in the human heart, with the exception of measurements performed on patients with coronary artery diseases, without controls (Gellerich et al. 1994). One of the challenges for the future management of cardiac disease will be to understand the involvement of mitochondrial fatty acid oxidation in heart failure. Also, targeting early events in mitochondrial dysfunction may help to design therapies to prevent the development of the disease before reaching an end-stage, where multiple injuries make it very difficult to find an ameliorative treatment.

Acknowledgments H.L. is supported by a fellowship from the Natural Sciences and Engineering Research Council of Canada. This work was supported by grants from the National Institutes of Health (P01 HL074237) and by the National Institute of Aging (P01 AG015885). Drs Bernard Tandler and Tatyana Klimova provided editorial assistance.

Open Access This article is distributed under the terms of the Creative Commons Attribution Noncommercial License which permits any noncommercial use, distribution, and reproduction in any medium, provided the original author(s) and source are credited.

\section{References}

Abozguia K, Clarke K, Lee L, Frenneaux M (2006) Nat Clin Pract Cardiovasc Med 3:490-498

Aragonés J, Schneider M, Van Geyte K, Fraisl P, Dresselaers T, Mazzone M, Dirkx R, Zacchigna S, Lemieux H, Nam Ho Jeoung NH, Lambrechts D, Bishop T, Lafuste P, Diez-Juan A, Harten SK, Van Noten P, De Bock K, Willam C, Tjwa M, Grosfeld A, Navet R, Moons L, Vandendriessche T, Deroose C, Wijeyekoon B, Nuyts J, Jordan B, Silasi-Mansat R, Lupu F, Dewerchin M, Pugh C, Salmon P, Mortelmans L, Gallez B, Gorus F, Buyse J, Sluse F, Harris RA, Gnaiger E, Hespel P, Van Hecke P, Schuit F, Van Veldhoven P, Ratcliffe P, Baes M, Maxwell P, Carmeliet P (2008) Nat Genet 40:170-180

Arbustini E, Diegoli M, Fasani R, Grasso M, Morbini P, Banchieri N, Bellini O, Dal Bello B, Pilotto A, Margini G, Campana C, Fortina P, Gavazzi A, Narula J, Vigano M (1998) Am J Pathol 153:1501-1510

Bartels GL, Remme WJ, Pillay M, Schönfeld DH, Cox PH, Kruijssen HA, Knufman NM (1992) J Cardiovasc Pharmacol 20:157-164

Beer M, Seyfarth T, Sandstede J, Landschütz W, Lipke C, Köstler H, von Kienlin M, Harre K, Hahn D, Neubauer S (2002) J Am Coll Cardiol 40:1267-1274

Bornstein B, Huertas R, Ochoa P, Campos Y, Guillen F, Garesse R, Arenas J (1998) Biochim Biophys Acta 1406:85-90

Boushel R, Gnaiger E, Schjerling P, Skovbro M, Kraunsoe R, Flemming D (2007) Diabetologia 50:790-796

Buchwald A, Till H, Unterberg C, Oberschmidt R, Figulla HR, Wiegand V (1990) Eur Heart J 11:509-516 
Chen Q, Camara AK, Stowe DF, Hoppel CL, Lesnefsky EJ (2007) Am J Physiol Cell Physiol 292:C137-C147

Chidsey CA, Weinbach EC, Pool PE, Morrow AG (1966) J Clin Invest $45: 40-50$

Conway MA, Allis J, Ouwerkerk R, Niioka T, Rajagopalan B, Radda GK (1991) Lancet 338:973-976

Conway MA, Bottomley PA, Ouwerkerk R, Radda GK, Rajagopalan B (1998) Circulation 97:1716-1723

Dörner A, Giessen S, Gaub R, Grosse Siestrup H, Schwimmbeck PL, Hetzer R, Poller W, Schultheiss HP (2006) Eur J Heart Fail 8:81-89

Dörner A, Schultheiss HP (2000) Herz 25:176-180

Dörner A, Schulze K, Rauch U, Schultheiss HP (1997) Mol Cell Biochem 174:261-269

Ferrari R, Cargnoni A, Ceconi C (2006) Pharmacol Res 53:435-9

Gellerich FN, Steinlechner R, Wyss M, Eberl T, Müller LC, Skladal D, Sperl W, Dapunt O, Margreiter R, Gnaiger E (1994) In: Gnaiger E, Gellerich FN, Wyss M (eds) What is Controlling Life? Modern Trends in BioThermo-Kinetics. Innsbruck Univ. Press, Innsbruck, pp 263-267

Gvozdjáková A, Kucharská J, Mizera S, Braunová Z, Schreinerová Z, Schrameková E, Pechán I, Fabián J (1999) Biofactors 9:301-306

Hardy CJ, Weiss RG, Bottomley PA, Gerstenblith G (1991) Am Heart J 122:795-801

Hoppel CL, Tandler B, Parland W, Turkay JS, Albers LD (1982) J Biol Chem 257:1540-1548

Ingwall JS, Atkinson DE, Clarke K, Fetters JK (1990) Eur Heart J $11: 108-115$

Jarreta D, Orus J, Barrientos A, Miro O, Roig E, Heras M, Moraes CT, Cardellach F, Casademont J (2000) Cardiovasc Res 45:860-865

Kalsi KK, Smolenski RT, Pritchard RD, Khaghani A, Seymour AM, Yacoub MH (1999) Eur J Clin Investig 29:469-477

Kerner J, Hoppel C (2000) Biochim Biophys Acta 1486:1-17

Khuchua ZA, Vasiljeva EV, Clark JF, Korchazhkina OV, Branishte TH, Kapelko VI, Kuznetsov AV, Ventura-Clapier R, Steinschneider AYa, Lakomkin VL, Ruuge EK, Saks VA (1992) Am J Cardiovasc Pathol 4:223-234

Kunz WS, Kudin A, Vielhaber S, Elger CE, Attardi G, Villani G (2000) J Biol Chem 275:27741-27745

Kunz WS, Kuznetsov AV, Schulze W, Eichhorn K, Schild L, Striggow F, Bohnensack R, Neuhof S, Grasshoff H, Neumann HW, Gellerich FN (1993) Biochim Biophys Acta 1144:46-53

Kuznetsov AV, Veksler V, Gellerich FN, Saks V, Margreiter R, Kunz WS (2008) Nat Protoc 3:965-976

Latronico MV, Elia L, Condorelli G, Catalucci D (2008) Int J Biochem Cell Biol 40:1643-1648

Lee SH, Doliba N, Osbakken M, Oz M, Mancini D (1998) J Thorac Cardiovasc Surg 116:344-349

Lemieux H, Garedew A, Blier PU, Tardif J-C, Gnaiger E (2006) Biochim Biophys Acta 1757:201-202

Lemieux H, Semsroth S, Gnaiger E (2008) Biochim Biophys Acta 1777:S80-S81

Lindenmayer GE, Sordahl LA, Harigaya S, Allen JC, Besch HRJ, Schwartz A (1971) Am J Cardiol 27:277-283

Marin-Garcia J, Ananthakrishnan R, Goldenthal MJ (1998) Mol Cell Biochem 179(21-6):21-26

Marin-Garcia J, Goldenthal MJ, Pierpont ME, Ananthakrishnan R (1995) J Card Failure 1:285-291

Maurer I, Zierz S (1992) Clin Investig 70:896-901

Maurer I, Zierz S (1993) Am J Cardiol 72:428-433

Maurer I, Zierz S (1994) Clin Investig 72:358-363

Mettauer B, Zoll J, Garnier A, Ventura-Clapier R (2006) Pflugers Arch 452:653-666

Mio Y, Bienengraeber MW, Marinovic J, Gutterman DD, Rakic M, Bosnjak ZJ, Stadnicka A (2008) Anesthesiology 108:612-620
Mital S, Loke KE, Addonizio LJ, Oz MC, Hintze TH (2000) J Am Coll Cardiol 36:1897-1902

Mital S, Loke KE, Chen JM, Mosca RS, Quaegebeur JM, Addonizio LJ, Hintze TH (2004) J Heart Lung Transplant 23:72-79

Murray AJ, Anderson RE, Watson GC, Radda GK, Clarke K (2004) Lancet 364:1786-1788

Murray AJ, Edwards LM, Clarke K (2007) Curr Opin Clin Nutr Metab Care 10:704-711

N'Guessan B, Zoll J, Ribera F, Ponsot E, Lampert E, Ventura-Clapier R, Veksler V, Mettauer B (2004) Mol Cell Biochem 256:267-280

Nascimben L, Ingwall JS, Pauletto P, Friedrich J, Gwathmey JK, Saks V, Pessina AC, Allen PD (1996) Circulation 94:1894-1901

Neubauer S, Horn M, Cramer M, Harre K, Newell JB, Peters W, Pabst T, Ertl G, Hahn D, Ingwall JS, Kochsiek K (1997) Circulation 96:2190-2196

Neubauer S, Krahe T, Schindler R, Horn M, Hillenbrand H, Entzeroth C, Mader H, Kromer E, Riegger GA, Lackner K (1992) Circulation 86:1810-1818

Palmer JW, Tandler B, Hoppel CL (1977) J Biol Chem 252:8731-8739

Pitkänen S, Merante F, McLeod DR, Applegarth D, Tong T, Robinson BH (1996) Pediatr Res 39:513-521

Puchowicz MA, Varnes ME, Cohen BH, Friedman NR, Kerr DS, Hoppel CL (2004) Mitochondrion 4:377-385

Quigley AF, Kapsa R, Esmore D, Hale G, Byrne E (2000) J Card Fail 6:47-55

Rossignol R, Faustin B, Rocher C, Malgat M, Mazat JP, Letellier T (2003) Biochem J 370:751-762

Rossignol R, Letellier T, Malgat M, Rocher C, Mazat JP (2000) Biochem J 347:45-53

Rustin P, Chretien D, Bourgeron T, Gerard B, Rotig A, Saudubray JM, Munnich A (1994) Clin Chim Acta 228:35-51

Saks VA, Belikova YO, Kuznetsov AV, Khuchua ZA, Branishte TH, Semenovsky ML, Naumov VG (1991) Am J Physiol 261:30-38

Saks VA, Veksler VI, Kuznetsov AV, Kay L, Sikk P, Tiivel T, Tranqui L, Olivares J, Winkler K, Wiedemann F, Kunz WS (1998) Mol Cell Biochem 184:81-100

Scheubel RJ, Tostlebe M, Simm A, Rohrbach S, Prondzinsky R, Gellerich FN, Silber RE, Holtz J (2002) J Am Coll Cardiol 40:2174-2181

Schultheiss HP (1992) Basic Res Cardiol 87:311-320

Seppet E, Eimre M, Peet N, Paju K, Orlova E, Ress M, Kovask S, Piirsoo A, Saks VA, Gellerich FN, Zierz S, Seppet EK (2005) Mol. Cell. Biochem. 270:49-61

Sharov VG, Todor AV, Silverman N, Goldstein S, Sabbah HN (2000) J Mol Cell Cardiol 32:2361-2367

Shinde SB, Save VC, Patil ND, Mishra KP, Tendolkar AG (2007) Clin Chim Acta 377:138-143

Sylvén C, Jansson E, Böök K (1988) Acta Physiol Scand 132:267-270

Sylvén C, Jansson E, Szamosi A, Böök K (1989) Scand J Thorac Cardiovasc Surg 23:63-67

Sylven C, Lin L, Jansson E, Sotonyi P, Fu LX, Waagstein F, Hjalmarsson A, Marcus C, Bronnegard M (1993) Cardiovasc Res 27:1295-1299

Tuunanen H, Ukkonen H, Knuuti J (2008) Curr Cardiol Rep 10:142-148

Unverferth DV, Lee SW, Wallick ET (1988) Am Heart J 115:139-146

Unverferth DV, Leier CV, Magorien RD, Croskery R, Svirbely JR, Kolibash AJ, Dick MR, Meacham JA, Baba N (1980) J Pharmacol Exp Ther 215:527-532

Veksler VI, Kuznetsov AV, Sharov VG, Kapelko VI, Saks VA (1987) Biochim Biophys Acta 892:191-196

Villani G, Attardi G (1997) Proc Natl Acad Sci USA 94:1166-1171

Villani G, Greco M, Papa S, Attardi G (1998) J Biol Chem 273:31829-31836

Weinstein ES, Benson DW, Fry DE (1986) J Surg Res 40:495-498 